\title{
ABORTUS DALAM PANDANGAN HUKUM ISLAM
}

\author{
Zulfahmi Alwi \\ UIN Alauddin Jl. Sultan Alauddin No. 63 Makassar \\ E-mail: elmahady79@yahoo.com
}

\begin{abstract}
Generally, abortion done in case of unwanted pregnancy and was usually motivated by a variety of factors, including economic, social, contraceptive failure in married couples, as well as sex of unmarriad couples. Islam strictly prohibits the act of abortion with social and economic motives. Abortion has absolutely forbidden unless it's motivation based on justifiable reason in Islam. Perpetrators of abortion may be punished by heavy penalty, which is to pay al-ghurrah or freeing slave. If the penalty of al-ghurrah is applied in contemporary life, the content of the sentence is determined by a court verdict. Islam greatly appreciates human existence since the early stages of events. Every effort to obstruct the growth of the fetus or to remove it from the womb before the arrival time of the birth naturally can not be tolerated.
\end{abstract}

Abstrak. Umumnya, aborsi dilakukan jika terjadi kehamilan yang tidak diinginkan dan biasanya dimotivasi oleh berbagai faktor, termasuk ekonomi, sosial, kegagalan kontrasepsi pada pasangan yang sudah menikah, serta hubungan seks di luar nikah. Islam melarang tindakan aborsi dengan motif sosial dan ekonomi. Aborsi benar-benar dilarang kecuali jika motivasi didasarkan pada alasan yang dapat dibenarkan dalam Islam. Pelaku aborsi dapat dihukum dengan hukuman yang berat, yaitu untuk membayar al-ghurrah atau membebaskan budak. Jika hukuman al-ghurrah diterapkan dalam kehidupan kontemporer, isi kalimat ditentukan oleh putusan pengadilan. Islam sangat menghargai eksistensi manusia sejak tahap awal peristiwa. Setiap upaya untuk menghambat pertumbuhan janin atau menghapusnya dari rahim sebelum masa kelahiran alami tidak dapat ditoleransi.

Kata kunci: aborsi, al-ghurrah, janin, ruh, hukum Islam. 


\section{PENDAHULUAN}

Secara kodrati manusia diciptakan berpasang-pasangan, laki-laki dan perempuan. ${ }^{1}$ Penciptaan manusia yang berpasangan membuat cenderung untuk melakukan hubungan biologis, guna melahirkan keturunan yang akan meneruskan kelangsungan eksistensi umat manusia. Namun tidak semua orang merasa senang dan bahagia dengan setiap kelahiran, terutama bila kelahiran itu merupakan kelahiran yang tidak diinginkan (unwanted pregnancy), karena faktor kemiskinan, faktor kegagalan kontrasepsi, akibat hubungan seks di luar nikah, dan sebagainya. ${ }^{2}$ Hal ini mengakibatkan banyak di antara perempuan yang menggugurkan kandungannya (aborsi) setelah terjadi pembuahan dalam tuba fallopii.

Di beberapa negara seperti Denmark, Inggris, Swedia, dan Amerika, ditemukan praktek aborsi untuk menghindari kelahiran bayi yang tidak diinginkan dalam jumlah yang cukup tinggi. Pada tahun 70-an, diduga praktek abortus illegal mencapai 100.000 kasus setiap tahunnya di Inggris. Sedangkan di Amerika jumlahnya jauh lebih besar, yaitu antara 200.000 dan 1.200 .000 kasus per tahun. ${ }^{3}$ Tindakan tersebut tidak hanya melenyapkan keberadaan janin dalam rahim sehingga menghilangkan kemungkinnan baginya untuk menikmati kehidupan dunia, tetapi sekaligus mengancam jiwa sang ibu yang mengandungnya.

Mengingat besarnya bahaya yang timbul dari tindakan tersebut, disamping abortus itu sendiri perbuatan asusila bila dipandang dari sudut moral dan etika, maka para ulama berusaha

${ }^{1}$ Q.S. al-Hujurāt (49): 13.

${ }^{2}$ Ali Ghufron dan Adi Heru Sutomo, Abortus, Bayi Tabung, Euthanasia, Transplantasi Ginjal, dan Operasi Kelamin dalam Tinjauan Medis, Hukum dan Agama Islam (Yogyakarta: Aditya Media, 1993), h. 8.

${ }^{3}$ David L. Sills (ed), International Encyclopedia of the Social Sciences, vol. 5 (New York: The Macmillan Company and the Free, 1972), h. 387; Martin Heller (ed), International Family Health Encyclopedia (London: Orbis Publishing, t.th.), h. 44. 
menjelaskan keberadaan abortus dalam perspektif hukum Islam. Dalam kajiannya, mereka berpedoman pada informasi Alquran, hadis, dan penemuan sains modern tentang proses kejadian manusia yang melalui beberapa tahapan kejadian.

Alquran telah menggambarkan suatu kisah yang menakjubkan tentang proses penciptaan manusia. Dalam banyak ayatnya, Alquran menandaskan bahwa manusia pertama-tama diciptakan berasal dari tanah liat. ${ }^{4}$ Pada penciptaan berikutnya, anak keturunan manusia diciptakan secara bertahap. ${ }^{5}$ Penciptaan tersebut bermula dari tahap al-nuft\}ah, kemudian alaqah, kemudian al-mud\}ghah, hingga berbentuk lebih sempurna sebagai calon bayi yang lalu berkembang menjadi "makhluk lain" (khalqan ākhar), yaitu makhluk manusia yang mempunyai keistimewaan-keistimewaan insaniyah. ${ }^{6}$ Penjelasan Alquran tersebut disempurnakan oleh sejumlah hadis Nabi saw yang mengurai tentang tenggang waktu setiap tahapan kejadian manusia dalam rahim sebagaimana diriwayatkan antara lain oleh al-Bukhārī dan Muslim. ${ }^{7}$

Petunjuk Alquran dan hadis tersebut dijadikan dasar dan hujah oleh para ulama dalam menyelesaikan berbagai problematika hukum Islam, termasuk hukum abortus yang dari waktu ke waktu terus menyeruak ke berbagai belahan bumi. Masalah tersebut tidak hanya melahirkan pandangan pro dan kontra, bahkan telah menjadi kasus moral yang tidak menutup kemungkinan akan menjadi norma baru dalam tatanan masyarakat.

${ }^{4}$ Q.S. al-Nisā' (4): 7.

${ }^{5}$ Q.S. Nūh (71): 14 .

${ }^{6}$ Q.S. al-Mu'minūn (23): 12-14. Lihat pula Ahmad Azhar Basyir, Refleksi atas Persoalan Keislaman; Seputar Filsafat, Hukum Politik, dan Ekonomi (Bandung: Mizan, 1994), h. 166-167.

${ }^{7} \mathrm{Abu}$ 'Abdillāh Muhammad bin Ismā’il al-Bukhārī, Șahīḥ al-Bukhārī, juz II (Indonesia: Maktabat Dahlan, t.th.), h. 1302; Abū al-Husain Muslim bin alHajjāj al Qusyairī al-Naisābūrī, Șahịh Muslim, juz IV (Indonesia: Maktabat Dahlān, t.th.), h. 2037. 


\section{PENGERTIAN ABORTUS}

Kata 'abortus' dalam bahasa Inggris disebut abortion, barasal dari bahasa Latin yang berarti gugur kandungan atau keguguran. ${ }^{8}$ Kata tersebut kemudian diserap kedalam bahasa Indonesia dengan tiga arti, yaitu: 1) terpencarnya embrio yang tidak mungkin lagi hidup (sebelum habis bulan keempat dari kehamilan), keguguran, keluron; 2) keadaan terhentinya pertumbuhan yang normal (tentang makhluk hidup); dan 3) guguran (janin). ${ }^{9}$

Para pakar hukum Islam menggunakan beberapa term untuk menyatakan tindakan abortus, seperti term isqāt, ijhāẹ, ilqā, taih dan inzāl. Kelima kata tersebut mengandung pengertian yang berdekatan, yaitu pengguguran janin dari kandungan sebelum mencapai kesempurnaannya.

Dalam al-Mu'jam al-Wasīt, kata al-isqāt diartikan dengan upaya seorang wanita meletakkan janinnya antara bulan keempat dan bulan ketujuh (dari usia janin). Sedangakan Ibn Fāris dan Ibn Manz\}ūr mengatakan bahwa akar kata tersebut berarti al-wuqu ${ }^{\prime}$ (pengguguran atau menjatuhkan), dalam hal ini menggugurkan atau menjatuhkan janin dari kandungan sebelum mencapai masa kesempurnaannya. ${ }^{10}$ Kata al-ijhād diartikan oleh Ibn Manzūr dengan al-izlāq (tergelincir). Dalam bahasa Arab, jika dikatakan ajhaḍt al-nāqat ijhādan, berati dia (unta betina tersebut) telah meletakkan janinnya sebelum mencapai kesempurnaannya. Pendapat tersebut antara lain dilontarkan oleh Abū Zaid dan al-

${ }^{8}$ Hassan Shadily dkk, Ensiklopedi Indonesia, jil. I (Jakarta: Ichtiar Baru Van Hoeve, 1980), h. 60; Med. Ahmad Ramli dan K. St. Pamontjak, Kamus Kedokteran (Jakarta: Djambatan, 1992), h. 254.

${ }^{9}$ Tim Penyusun Kamus Pusat Pembinaan dan Pengembangan Bahasa, KamusBesar Bahasa Indonesia (Jakarta: Balai Pustaka, 1990),h. 2.

${ }^{10}$ Ibrāhīm Anīs dkk., al-Mu'jam al-Wasịt (T.tp.: t.p., t.th.), h. 435; Abū alHusayn Ahmad bin Fāris bin Zakariyā, Mu'jam Maqāyīs al-Lugah, juz III (T.tp.: Dār al-Fikr, 1394 H./1979), h. 86; Ibn Manżūr, Lisān al-'Arab, jilid II (Bairut: Dār Lisān al-'Arab, t.th.), h. 163. Bandingkan dengan Edward William Lane, An Arabic-Englis Lexicon (Lebanon: Librarie Du Liban, 1968), h. 1379-1380. 
Asma'̄̄. Pandangan yang lebih tegas dinyatakan oleh Ibrāhīm Anīs dengan mengatakan bahwa kata ijhāẹ berarti keluarnya janin dari rahim (uterus) sebelum mencapai usia empat bulan. ${ }^{11}$

Kata ilqā' berarti al-tarh yang berarti melemparkan atau membuang. ${ }^{12}$ Dalam hal ini kata ilqā' dapat digunakan untuk pengertian umum, sehingga mambuang atau meletakkan janin (sebelum mencapai masa kesempurnaannya) dapat diterjemahkan dengan ilqā' al-janīn. Kata al-taih\} berasal dari kata tāha yatīhu, yang berarti halaka (binasa atau hancur). Dalam penerapannya, kata tersebut dapat pula berarti hancur atau binasa, jatuh atau menjatuhkan. ${ }^{13}$ Adapun kata inzāl berasal dari kata anzala yunzilu, yang berakar kata dari kata nazala menunjukkan arti turun, jatuh atau gugurnya sesuatu. ${ }^{14}$ Berdasarkan penjelasan di atas, salah satu dari kelima kata tersebut dapat digunakan untuk menunjukkan perbuatan abortus.

Abortus dalam Encyclopedia Americana, diartikan dengan pengguguran atau penghancuran hasil konsepsi (zygote) atau janin (fetus) sebelum masa kelahiran. ${ }^{15}$ Pernyataan senada diungkapkan oleh Sardikin Ginaputra dari Fakultas Kedokteran Universitas Indonesia yang memberikan pengertian abortus dengan pengakhiran kehamilan atau hasil konsepsi sebelum janin dapat hidup di luar kandungan. ${ }^{16}$ Pengakhiran kehamilan atau hasil konsepsi tersebut dilakukan sebelum masa gestasi

\footnotetext{
${ }^{11} \mathrm{Ibn}$ Manżūr, Lisān... ., jilid I, h. 523; Ibn Fāris, Mu'jam... ., juz I, h. 489; Edward William Lane, An Arabic... ., h. 477; Ibrāhīm Anīs, al-Mu'jam... ., h. 143.

${ }^{12}$ Ibrāhīm Anīs, al-Mu'jam... ., h. 836; Ibn Manżūr, Lisān... ., jilid III, h. 389; Ibn Fāris, Mu'jam... ., juz V, h. 260.

${ }^{13} \mathrm{Ibn}$ Fāris, Mu'jam... ., juz III, h. 430; Ibn Manżūr, Lisān... ., jilid III, h. 622623; Ibrāhīm Anīs, al-Mu'jam... ., h. 573.

${ }^{14}$ Ibrāhīm Anīs, al-Mu'jam... ., h. 915; Ibn Fāris, Mu'jam... ., juz V, h. 418; Ibn Manżūr, Lisān... ., jilid III, h. 619.

${ }^{15}$ The Encyclopedia Americana, jilid I (U.S.A.: Americana Corporaion), h. 42.

${ }^{16}$ Masjfuk Zuhdi, Masail Fiqhiyah (Jakarta: Haji Masagung, 1993), h. 77. Pengertian serupa dapat dilihat dalam "Encyclopedia Americana", jilid I, h. 42.
} 
(gestation) ${ }^{17} 28$ minggu atau sebelum janin mencapai berat 1000 gr. ${ }^{18}$ Pada masa itu, janin belum mampu hidup secara mandiri sehingga mengeluarkannya dari janin dapat mengakibatkan kematian atau terhentinya pertumbuhan janin.

Ilmu Kedokteran membedakan antara abortus yang terjadi dengan sendirinya atau tanpa kesengajaan, yang disebut abortus spontaneous dan abortus yang terjadi dengan kesengajaan disebut abortus provocatus.

Abortus Spontaneous adalah abortus yang terjadi dengan tidak didahului faktor-faktor mekanis ataupun medis, tetapi disebabkan semata-mata oleh faktor-faktor alamiah. ${ }^{19}$ Abortus macam ini, bisa terjadi akibat keracunan, kecelakaan, kaget, terpukul atau penyakit yang diderita oleh calon ibu, seperti penyakit cacar, sifilis dan kencing manis. ${ }^{20}$ Akan tetapi penyebab yang paling dominan (50-60\%) adalah cacatnya bibit, yakni telur atau sperma yang tidak sempurna. ${ }^{21}$ Dengan demikian, abortus spontaneous terjadi dengan sendirinya dan diluar kemampuan orang yang bersangkutan untuk menghindarinya.

Sementara itu, abortus provocatus dapat dibedakan pula atas abortus artificialis therapicus dan abortus provocatus criminalis. Abortus artificialis therapicus adalah abortus yang dilakukan oleh dokter atas dasar indikasi medis. Abortus jenis ini dilakukan untuk menjaga kepentingan ibu, baik fisik maupun mental. Misalnya, kehamilan yang membahayakan jiwa si ibu jika

\footnotetext{
${ }^{17}$ Masa gestasi disebut juga dengan masa kehamilan. Lihad Med. Ahmad Ramali dan K. St. Pamoentjak, Kamus Kedokteran... ., h. 114.

${ }^{18}$ Hassan Shadily, Ensiklopedi Indonesia, Jilid I, h. 60; Encyclopedia Americana, Jilid I, h. 42; E. Nugroho dkk., Ensiklopedi Nasional Indonesia, jilid I (Jakarta: PT. Cipta Adi Pustaka, 1990), h. 22. Bandingkan dengan beberapa defenisi para ahli dalam Rustam Mochtar, Sinopsis Obstetri: Obstetri Fisiologi, Obstetri Patologi (Jakarta: Penerbit Buku Kedokteran EGC, 1990), h. 231.

${ }^{19}$ Ibid., h. 234.

${ }^{20}$ Martin Heller (ed.), International Family... ., h. 15-17; Masjfuk Zuhdi, Masail Fiqhiyah, h. 77; Rustam Mochtar, Sinopsis Obstetri... ., h. 232-233.

${ }^{21}$ E. Nugroho dkk., Ensiklopedi Nasional..., jilid I, h. 22
} 
diteruskan, karena menderita penyakit-penyakit yang sudah berat, seperti penyakit TBC, dan penyakit ginjal. Sedangkan abortus provocatus criminalis adalah abortus yang dilakukan tanpa dasar medis. Abortus jenis ini terkadang dilakukan orang untuk meniadakan hasil hubungan seks di luar pernikahan atau untuk mengakhiri kehamilan yang tidak dikehendaki karena alasan ekonomi dan lain-lain. ${ }^{22}$ Banyak pihak tidak menyetujui abortus jenis terakhir berdasarkan pertimbangan etika, namun di beberapa negara banyak yang melakukannya.

\section{KEDUDUKAN HUKUM ABORTUS}

Pada dasarnya, orang melakukan abortus apabila terjadi 'kehamilan tidak dikehendaki', baik didalam perkawinan ataupun diluar perkawinan. Diluar perkawinan, abortus sering terjadi sebagai akibat dari hubungan seks yang tidak sah, sedang 'ayah' dan 'ibu' si janin menghindarkan diri dari konsekuensi perbuatan mereka. Sementara di dalam perkawinan, tindakan tersebut terkadang dilatarbelakangi oleh kegagalan kontrasepsi atau kekhawatiran pasangan suami istri tidak mampu membiayai sang anak. $^{23}$

Abortus yang terjadi tanpa disengaja atau karena alasan medis demi menjaga kemaslahatan tidak mengandung konsekuensi hukum dalam Islam. Namun sebaliknya, tindakan abortus yang dilakukan tanpa dasar medis atau alasan pembenaran dalam Islam mengandung konsekuensi hukum.

Perbincangan ulama tentang kedudukan hukum tindakan abortus sangat dipengaruhi oleh petunjuk Alquran dan hadis Nabi saw tentang tahap kejadian dan pertumbuhan janin dalam rahim. Kebanyakan ulama menyandarkan persoalan abortus pada hadis-

${ }^{22}$ Masjfuk Zuhdi, Masail Fiqhiyah..., h. 77; E. Nugroho dkk, ibid. ; Hassan Shadily, Ensiklopedi ..., jil. I, h. 60

${ }^{23}$ Ali Gufran Mukti dan Adi Heru Sutomo, Abortus, Bayi Tabung, Euthanasia, Transplantasi Ginjal dan Operasi Kelamin dalam Tinjauan Medis, Hukum dan Agama Islam (Yogyakarta: Aditya Media, 1993), h. 8 dan 11. 
hadis yang menyebutkan bahwa proses perkembangan janin dalam kandungan memakan waktu 120 hari sebelum ditiupkan ruh. Peniupan ruh tersebut menjadi faktor penting dalam menentukan hukum abortus.

\section{Abortus Pra Peniupan Ruh}

Para ulama melontarkan pendapat yang berbeda terhadap tindakan abortus yang dilakukan sebelum janin diberi nyawa. ${ }^{24}$ Perbedaan tersebut dapat diklasifikasikan dalam tiga golongan. Pertama, pendapat yang mengatakan haram pada setiap tahap pertumbuhan dan kejadian manusia. Kedua, pendapat yang membolehkan pada setiap tahap kejadian manusia. Ketiga, pendapat yang membolehkan pada salah satu tahap tetapi mengharamkan pada tahap lainnya.

Ulama Mazhab al-Zhāhirī, sebagaimana dikemukakan ulama al-Azhar, ${ }^{25}$ mengharamkan abortus sebelum ditiupkan ruh pada setiap tahap pertumbuhan janin (al-nutfah, al-mudghah dan alalaqah). Pandangan ini merupakan pendapat terkuat dalam Mazhab al-Mālikī, meskipun ada diantara ulama mazhab ini mengatakan hanya makruh bila dikeluarkan sebelum melalui masa 40 hari setelah pembuahan. Pendapat senada dikemukakan oleh sebagian ulama mazhab al-Syāfi'î dan sebagian ulama mazhab al-Hanafī.

Disamping berpedoman pada hadis-hadis tentang reproduksi manusia, menurut mereka, tahap penciptaan dan pembentukan manusia dimulai setelah cairan sperma jatuh dan menetap dalam rahim. Cairan sperma yang telah menyatu dengan ovum tersebut kemudian tumbuh sejalan dengan fisiologi

\footnotetext{
${ }^{24}$ Lihat misalnya Ahmad al-Syirbāșī, Yas'alūnaka fī al-Dīn wa al-Hayāh (Beirut: Dār al-Jail, 1980), h. 216.

${ }^{25}$ Al-Azhar al-Syarīf, Bayān li al-Nās, juz II (t.tp.: al-Matba'at al-Azhar, t.th.), h. 256.
} 
petumbuhan janin menuju kepada hidup. Karenanya, cairan tersebut tidak dapat dianiaya apalagi digugurkan. ${ }^{26}$

Al-Gazali ${ }^{27}$ melontarkan pernyataan serupa bahwa pertumbuhan janin melalui tahap yang bertingkat-tingkat. Tahap awal bermula dari pertemuan sperma dan ovum yang dikenal dengan tahap al-nutfah. Menganiaya dan merusak pertumbuhan janin pada tahap awal tersebut adalah suatu kejahatan, bila telah menjadi al-mudghah dan al-alaqah, maka merusaknya merupakan kejahatan yang lebih keji. Apabila janin telah diberi nyawa dan telah berbentuk manusia sempurna, maka merusaknya merupakan kejahatan yang bertambah lebih keji lagi. Puncak kekejian kejahatan apabila ditujukan kepada anak yang telah lahir dalam keadaan hidup. Demikianlah keduanya telah mengharamkan penghancuran dan pengguguran janin pada setiap tahap pertumbuhannya.

Pendapat kedua adalah golongan yang membolehkan pengguguran pada tahap tertentu dan melarang pada tahap lainnya. Pandangan ini antara lain dikemukakan oleh ulama Mazhab al-Mālikī dan sebagian ulama Mazhab al-Syāfi'̄̄.

Ulama Mazhab al-Mālikī memandang bahwa makruh hukumnya menggugurkan kandungan pada tahap al-nutfah, sedangkan pada tahap al-alaqah dan al-mudghah hukumnya haram. Sementara itu, al-Māwardī dan sebahagian ulama alSyāfi'î tidak memberikan hukuman apapun bagi pelaku abortus apabila janin yang digugurkan pada tahap al-'alaqah. Hukuman baru dapat dijatuhkan jika janin telah memperoleh bentuknya pada tahap al-mudghah. ${ }^{28}$ Pernyataan tersebut menunjukkan

${ }^{26}$ Ibid.

${ }^{27}$ Al-Ghazālī, Ihyā' 'Ulūm al-Dīn, juz II (t.tp.: Dār Ihyā' al-Kutub al'Arabiyyah, t.th.), h. 53; Mahmūd Syaltūt, al-Fatāwā (Kairo: Dār al-Qalam, t.th.), h. 290-291. Lihat pula Ahmad Azhar Basyir, Refleksi atas Persoalan Keislaman Seputar Filsafat, Hukum, Politik dan Ekonomi (Bandung: Mizan, 1994), h. 170.

${ }^{28} \mathrm{Abd}$ al-Rahmān al-Jazīrī, Kitāb al-Fiqh ‘alā al-Mazāhib al-Arba'ah, juz V (Beirut: Dār al-Kutub al-'Ilmiyyah, 1410 H/1990), h. 328; Abū al-Hasan 'Alī bin 
bahwa sebagian ulama al-Syāfi'ī masih mentolerir pengguguran pada tahap al-nutfah dan al-alaqah dan mengharamkannya ketika janin telah memasuki usia al-mudghah.

Secara umum, penulis tidak menemukan alasan tegas yang dijadikan argument untuk memperkuat pendapat mereka kecuali pendapat yang membolehkan pengguguran pada tahap al-nutfah tetapi haram pada tahap al-alaqah dan al-mudghah. Mereka berpedoman kepada sabda Rasulullah saw yang diriwayatkan oleh Muslim dari Ibn Mas'ūdtentang pengutusan malaikat kedalam rahim setelah al-nutfah berusia 42 hari. ${ }^{29}$ Kandungan hadis tersebut menunjukkan bahwa pembentukan janin, penciptaan pendengaran, penglihatan, kulit, daging dan tulang baru terjadi setelah melewati masa al-nutfah. Bagi mereka, hadis tersebut memberi isyarat bahwa pada masa al-nuțfah janin belum diberi bentuk dan masih berupa cairan, sehingga mengugurkannya tidak mengandung konsekuensi hukum.

Sementara itu, al-Māwardī tidak memberikan hukuman bagi pelaku abortus pada tahap al-'alaqah karena beliau menganggap keberadaan al-'alaqah sama dengan keberadaan al-nutfah, sebagaimana telah menjadi ijma ulama. Jika tidak ada hukuman bagi pelaku abortus pada tahap al-nutfah, maka demikian pula halnya dengan tahap al-'alaqah. ${ }^{30}$

Selanjutnya adalah golongan yang membolehkan abortus pada setiap tahap kejadian manusia sebelum pemberian ruh. Pendapat ini antara lain dikemukakan oleh Ibn Hazm, ulama Mazhab al-Zaydī dan sebagian ulama Mazhab al-Hanafī.

Mereka berpendapat bahwa menggugurkan kandungan sebelum janin diberi nyawa dibolehkan dan janin dipandang

Muhammad bin Habīb al-Māwardī, al-Hāwī al-Kabīr, juz XVI (Beirut: Dār alFikr, 1414 H/1994), h. 210.

${ }^{29}$ Muslim, Sahịh..., juz IV, h. 2037.

${ }^{30} \mathrm{Abū}$ al-Hasan 'Al̄̄ bin Muhammad bin Habīb al-Māwardī, al-Hāwī alKabīr, juz XVI (Beirut: Dār al-Fikr, 1414 H/1994), h. 210. 
bernyawa apabila telah melalui proses pertumbuhan selama 120 hari. ${ }^{31}$ Akan tetapi sebagian ulama al-Hanafī lainnya memandang bahwa menggugurkan kandungan sebelum berumur 120 hari hukumnya makruh jika tidak ada uzur. Uzur yang dimaksud antara lain terputusnya air susu ibu pada saat kehamilan sementara ayah si calon bayi tidak mampu menyusukannya kepada orang lain dan dikhawatirkan anak akan mati. ${ }^{32}$ Kondisi seperti ini, menurut sebagian ulama al-Hanafī tersebut, membolehkan seseorang melakukan abortus.

Mereka membolehkan pengguguran pada setiap tahap pertumbuhan janin sebelum ditiupkan ruh karena setiap yang belum diberi nyawa tidak tergolong sebagai manusia. Keberadaan janin sebelum ditiupkan ruh tidak diperhitungkan, karenanya tidak dibangkitkan di hari Kemudian. Oleh karena keberadaannya tidak diperhitungkan, maka tidak ada larangan untuk menggugurkannya. Sedangkan ulama Mazhab al-Hanbalī, sebagaimana dikemukakan oleh Ibn Qudāmah, ${ }^{33}$ berpendapat bahwa perempuan yang menggugurkan kandungannya sebelum membentuk manusia tidak dikenai sanksi, karena tidak dipandang sebagai janin. Ibn Qudāmah tidak menjelaskan, apakah mereka membolehkan atau mengharamkan tindakan abortus yang dimaksud, tetapi tidak adanya sanksi yang diberikan kepada pelaku mengisyaratkan bahwa mereka membolehkannya pada tahap tersebut.

Memperhatikan ketiga pendapat tersebut di atas, penulis lebih sependapat dengan pendapat pertama yang mengharamkan

\footnotetext{
${ }^{31}$ Muhammad Amīn bin 'Ābidīn, Hāsyiyah Ibn 'Ābidīn, juz III (Mesir: Mușțāfā al-Bābī al-Halabī, 1386 H/1966), h. 176; Abū Muhammad 'Alī bin Ahmad bin Sa'īd bin Hazm, al-Muhalā, juz XII (Mesir: Maktabat al-Jumhuriyyat al-'Arabiyyah, 1391 H/1971), h. 386.

${ }^{32} \mathrm{Al}$-Azhar al-Syarîf, Bayān li al-Nās..., h. 256-257. Lihat juga Ahmad alSyirbāsī, Yas'alūnaka..., h. 216; Ahmad Azhar Basyir, Refleksi..., h. 169-170.

${ }^{33}$ Muwaffiq al-Dīn AbīMuhammad 'Abdillāh bin Ahmad bin Qudāmah, alMughnīwa al-Syarh al-Kabīr 'alā Matn al-Mughnī, juz VIII (Beirut:Dār al-Fikr, 1412 H/1992), h. 392.
} 
pengguguran kandungan pada setiap tahap kejadian manusia, sejak tahap al-nutfah hingga janin berbentuk manusia sempurna. Sebagaimana dikemukakan pada uraian dalam naqd al-matan terdahulu, tahap pertama kejadian manusia bermula setelah terjadi pembuahan (fertilisasi), yaitu peristiwa pertemuan sel mani laki-laki (sperma) dan ovum perempuan pada tuba falopii, yang kemudian disebut hasil konsepsi atau al-nutfah. Hasil konsepsi kemudian tumbuh dan mengalami perkembangan secara berangsur-angsur hingga memperoleh bentuk dan diberi nyawa. Oleh karena itu, menggugurkannya adalah suatu kejahatan sebab tindakan tersebut telah menghancurkan dan menghentikan pertumbuhannya menjadi manusia sempurna, yang justru harus dilindungi dan dihormati. Kadar kejahatan itu makin besar bila dilakukan setelah diberi nyawa, terlebih lagi jika bayi yang telah dilahirkan dibuang atau dibunuh.

Membahas fenomena peniupan ruh, menarik untuk dibahas QS. al-Mu'minūn ayat 14 , seperti berikut:

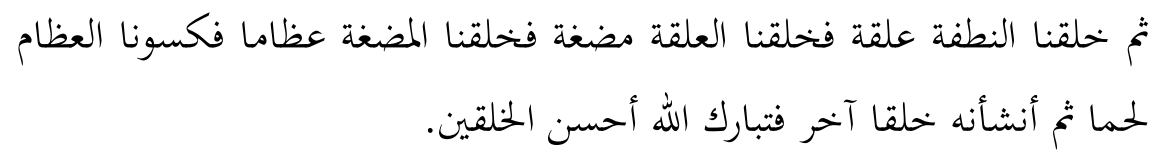

Kemudian air mani itu Kami jadikan segumpal darah, lalu segumpal darah itu Kami jadikan segumpal daging, dan segumpal daging itu Kami jadikan tulang belulang, lalu tulang belulang itu Kami bungkus dengan daging. Kemudian Kami jadikan dia makhluk yang (berbentuk) lain. Maka Maha Sucilah Allah, Pencipta Yang Paling Baik.

Disini Sayyid Qutub mengartikan peniupan ruh pada janin setelah berbentuk manusia lengkap dengan 'ruh insaniah' secara metafisik, yaitu ruh yang membedakan manusia dengan makhluk hidup lain, bukan hidup secara biologis atau hidup ruh hayawani. Ruh insaniah adalah pemberian Tuhan berupa keistimewaankeistimewaan pada manusia dalam pertumbuhannya yang memungkinkan mampu memikul amanat Allah. Sedangkan ruh hidup hayawani sebenarnya telah dimiliki pada saat pembuahan terjadi, sebab pembuahan secara biologis hanya mungkin apabila 
bibit laki-laki dan bibit perempuan merupakan bibit yang hidup pula. ${ }^{34}$ Penafsiran Sayyid Qutub ini memberi isyarat bahwa beliau telah mengakui adanya kehidupann secara biologis sejak terjadi pembuahan dan mengharamkan abortus sejak peristiwa tersebut. Selain itu, Sayyid Qutb membedakan proses kejadian dan perkembangan janin manusia dan janin makhluk lain (hewan). Jika janin manusia mengalami pertumbuhan jasadiyah yang mirip dengan janin hewan, maka janin manusia masih dapat berkembang hingga memiliki keistimewaan-keistimewaan yang tidak dimiliki oleh hewan.

Adapun pendapat golongan kedua di atas mengatakan bahwa pembentukan tulang, daging dan lain-lain terjadi setelah melewati masa al-nutfah (42 hari), memang mendapat dukungan secara eksplisit dari hadis Nabi saw. Akan tetapi, hadis tersebut tidak menafikan adanya pertumbuhan pada masa al-nutfah, sehingga menghentikannya juga berarti menghambat pertumbuhannya.

Ungkapan lebih tegas tentang adanya pertumbuhan sejak masa al-nutfah dapat dilihat pada hadis-hadis tentang masa 40 hari bagi setiap tahap reproduksi manusia. ${ }^{35}$ Dalam hadis-hadis tersebut dijelaskan bahwa tahap awal kejadian manusia bermula dari pertemuan sperma dan ovum, yang dalam bahasa hadis-hadis tersebut digunakan istilah yujma', kemudian mengalami pertumbuhan melalui fase-fase al-nutfah, al-alaqah dan almudghah, hingga ditiupkan ruh dan membentuk manusia sempurna. Hadis-hadis tersebut secara implisit mengakui adanya pertumbuhan setelah sperma dan ovum bersatu.

Demikian pula halnya dengan pendapat golongan ketiga yang menjelaskan implikasi pemberian nyawa terhadap

\footnotetext{
${ }^{34}$ Sayyid Qutb, Fī Zilāl al-Qur'ān, juz IV (Kairo: Dār al-Masyrūq, 1412 H/1992), h. 2459. Lihat juga Ahmad Azhar Basyir, Refleksi..., h. 168-169.

${ }^{35}$ Lihat misalnya riwayat Ibn Mas'ūd dalam Abū 'Āsā Muhammad bin 'Īsā al-Tirmizī, Sunan al-Tirmizī, juz III (Indonesia: Maktabat, Dahlan, t.th.) h.302.
} 
kebangkitan manusia di hari kemudian, sehingga membolehkan abortus sebelum janin diberi nyawa. Hanya saja, sebagaimana telah dikemukakan, jika hasil konsepsi dibiarkan berkembang dalam rahim, dia akan tumbuh hingga diberi nyawa dan menjadi manusia yang lengkap anggotanya. Apabila janin telah diberi nyawa, berarti kelak dia pun akan dibangkitkan di hari kemudian. Oleh karena itu, menganiaya dan merusaknya sebelum diberi nyawa tanpa alasan hukum, adalah perbuatann dosa.

Demikianlah, tahap kejadian manusia telah dimulai sejak terjadi persatuan antara sel sperma laki-laki dan sel telur (ovum) perempuan, sehingga menggugurkannnya tanpa alasan yang dibenarkan dalam agama adalah haram.

\section{Abortus Pasca Peniupan Ruh}

Para ulama sepakat untuk mengharamkan abortus yang dilakukan pada waktu janin telah diberi nyawa, yaitu setelah janin melalui proses pertumbuhan selama empat bulan atau 120 hari. ${ }^{36}$ Menggugurkan kandungan setelah janin diberi nyawa tanpa ada alasan atau indikasi medis yang dibenarkan dalam agama, dipandang sebagai tindakan pidana yang disamakan dengan pembunuhan terhadap manusia yang telah sempurna wujudnya. ${ }^{37}$ Inilah tindakan pengguguran yang dikenal dengan istilah abortus provocatus criminalis (الإسقاط الإختياري).

Pada kondisi tertentu, seseorang yang sedang mengandung diperhadapkan oleh dua pilihan yang merugikan; menyelamatkan jiwanya atau menggugurkan kandungannya. Hal itu antara lain dapat diketahui dari hasil pemeriksaan medis yang menunjukkan bahwa jiwa sang ibu akan terancam bila janin dalam kanndungannnya tetap dipertahankan. h. 169 .

${ }^{36}$ Ahmad Syirbāsī, Yas'alūnaka..., h. 216 ; Ahmad Azhar Basyir, Refleksi...,

${ }^{37}$ Mahmūd Syaltūt, al-Islām 'Aqīdah wa Syari'ah (Kairo: Dār al-Qalam, 1966), h. 289-290; Yūsuf al-Qardhāwī, al-Halāl wa al-Harām fī al-Islām (Beirut: Maktab al-Islāmī, 1978), h. 195. 
Menanggapi kenyataan tersebut, jumhur ulama, termasuk ulama-ulama kontemporer seperti Mahmūd Syaltūt ${ }^{38}$ dan Yūsuf al-Qardhāwi, ${ }^{39}$ membenarkan tindakan abortus guna menyelamatkan jiwa sang ibu. Dalam hal seperti ini, keselamatan ibu lebih diutamakan daripada keselamatan bakal bayi, apalagi bila kehidupan ibu benar-benar telah nyata sedangkan bakal bayi tidak dapat diyakinkan akan lahir dalam keadaan hidup. Itu berarti jumhur ulama membolehkan abortus artificialis therapicus (الإسقاط الضروري) untuk menyelamatkan jiwa sang ibu.

Pandangan ini didasarkna atas kaidah ushul fiqhi yang mengatakan الضرر يزال atau kemudaratan harus dihilangkan. ${ }^{40}$ Disamping itu, ada juga kaidah ushul fiqhi lainnya yang berbunyi: ${ }^{41}$

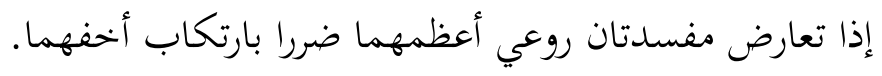

Apabila bertemu dua mafsadah, maka yang lebih besar kemudaratannya harus diutamakan dengan mengorbankan yang lebih kecil kemudaratannnya.

Dalam hal ini, kemudaratan yang ditimbulkan akibat kematian sang ibu lebih besar dampaknya bila dibandingkan dengan kematian sang janin. Dengan kata lain, kemudaratan yang mengandung unsur al-mașlahah $h^{42}$ lebih besar diutamakan

${ }^{38}$ Mahmūd Syaltūt, ibid., h. 290.

${ }^{39}$ Yūsuf al-Qardhāwī, al-Halāl..., h. 195.

${ }^{40}$ Muhammad Shidqī bin Ahmad Burnū, al-Wajīz fī̄ldhāh Qawā’id al-Fiqh al-Kulliyyah (Beirut: Mu'assasat al-Risālah, 1440 H/1983), h. 81; 'Abd al-Wahhāb Khallâf, 'IIm Ușūl al-Fiqh (t.tp.: Maktabat al-Da'wat al-Islāmiyyah, t.th.), h. 207.

${ }^{41}$ Al-Burnū, ibid., h. 83; Khallāf, ibid., h. 208. Bandingkan Muhammad Abū Zahrah, Ușūl al-Fiqh (t.tp.: Dār al-Fikr al-'Arabī, t.th.), h. 377.

${ }^{42}$ Menurut al-Syātibī, al-mașlaḥah ialah apa yang melandasi tegaknya kehidupan manusia dan terwujudnya kesempurnaan hidup, serta yangmemungkinkan manusia memperoleh keinginan-keinginan jasmaniah dan akliyah secara mutlak, sehingga manusia itu dapat merasakan kenikmmatan dalam hidupnya. Selanjutnya al-Syātibī membagi al-mașlahah yang menjadi tujuan diturunkannya syariat kedalam tiga macam, yaitu al-ḍarüriyyah, alhājiyyah dan tahsīniyyah. Selengkapnya lihat Abū Ishāq al-Syātibī, al- 
atas kemudaratan yang mengandung unsur al-mașlahahnya lebih kecil. Oleh sebab itu, dalam keadaan amat mendesak (darurat) seperti ini, abortus dapat dibenarkan dalam hukum Islam untuk menyelamatkan jiwa sang ibu.

Berbeda halnya dengan abortus yang dilakukan akibat 'kehamilan yang tidak dikehendaki' karena didorong oleh faktorfaktor lain, misalnnya faktor ekonomi, sosial atau rasa malu karena kehamilan terjadi akibat hubungan diluar nikah (zina), maka Islam tidak mentolerirnya.

Telah menjadi kebiasaan bangsa Arab Jahiliah membunuh atau mengubur hidup-hidup bayi perempuan mereka sesaat setelah dilahirkan. Kebiasaan ini dilakukan karena mereka merasa malu dan menjadi bahan ejekan masyarakat bila mempunyai anak perempuan. Menurut anggapan mereka, anak perempuan hanya akan menambah beban hidup, tanpa dapat memberikan kegunaan untuk memperkuat kabilah. Allah mengabadikan kebiasaan buruk tersebut dan mengecam keras apa yang mereka lakukan terhadap anak perempuan. ${ }^{43}$ Jika kecaman Tuhan terhadap kebiasaan bangsa Arab jahiliah dianalogikan dengan tindakan abortus yang didorong oleh faktor ekonomi, sosial dan rasa malu tersebut, maka jelas hal tersebut tidak dibenarkan.

Beberapa ulama dengan tegas mengharamkan abortus akibat hubungan seksual di luar nikah pada setiap tahap pertumbuhan janin. Pendapat ini didasarkan atas firman Allah swt yang tidak membenarkan dosa seseorang dipikul kepada orang lain melainkan kembali kepada dirinya sendiri. ${ }^{44}$ Janin yang

Muwāfaqāt fĩ Ușūl al-Syarīah, juz II (Beirut: Dār al-Kutub al-‘llmiyyah, t.th.), h. 7-10. Lihat juga Hamka Haq, “Aspek-aspek Teologis dalam Konsep Mașlahah Menurut al-Syātibī sebagai Terdapat dalam al-Muwāfaqāt," Disertasi (Jakarta: Program Pascasarjana IAIN Syarif Hidayatullah, 1989), h. 5-7 dan 297.

${ }^{43}$ QS. al-Nahl (16): 58-59.

${ }^{44}$ Lihat misalnya QS. al-An‘ām (6): 164; QS. al-Isrā’ (17): 15; QS. Fātir (35): 18; QS. al-Zumar (39): 7; dan QS. al-Najm (53): 38. 
menjadi korban hubungan seksual yang tidak sah, tetap berhak untuk tumbuh dan lahir ke dunia. Dosa yang dipikul ibunya tidak dapat dibebankan kepada janin yang tidak berdosa, dengan menggugurkannya. Bukan hanya itu, bila pengguguran tetap dilakukan untuk menutup rasa malu, maka yang bersangkutan telah melanggar larangan berganda, yaitu larangan hubungan diluar nikah dan larangan menggugurkan kandungan, berarti dosanya pun berganda.

Adapun abortus yang dilakukan atas pertimbangan khawatir tidak mampu mencukupi kebutuhan anak, secara sederhana dapat diperhadapkan dengan pernyataan Allah yang melarang membunuh anak karena takut miskin. ${ }^{45}$ Membunuhnya adalah suatu dosa besar, padahal Allah telah menjamin sumbersumber rezki untuk si anak dan orang tuanya. Dengan jelas Allah mengatakan bahawa tidak ada makhluk hidup di dunia ini yang tidak disediakan sumber rezkinya oleh Allah. ${ }^{46}$

\section{HUKUMAN BAGI PELAKU ABORTUS}

Berdasarkan pembahasan di atas, diketahui bahwa abortus dalam pandangan Islam termasuk perbuatan keji dan merupakan suatu kejahatan (الجناية). ${ }^{47}$ Sebagaimana kejahatan lainnya, kejahatan abortus yang dilakukan dengan sadarsudah tentu mengandung konsekuensi hukuman bagi para pelakunya.

Menganggapi hukuman yang harus diterima oleh pelaku abortus, penulis merujuk kepada ketetapan Rasulullah saw keatas

${ }^{45}$ QS. al-Isrä' (17): 31.

${ }^{46}$ QS. al-Hūd (11): 6.

${ }^{47}$ Al-Jināyah yang juga disebut al-jarimmah adalah dosa, maksiat atau segala kejahatan yang dilakukan oleh seseorang. Dalam syariat, al-jināyah dapat dibedakan atas pengertian umum dan khusus. Secara umum, al-jināyah adalah setiap perbuatan yang diharamkan oleh syariat, baik terhadap jiwa, harta maupun yang lainnya. Sedangkan al-jināyah secara khusus adalah kejahatan yang ditujukan kepada jiwa seseorang atau anggota badannya, yaitu dengan membunuh, melukai atau memukul. Wahbat al-Rakhīlī, al-Fiqh alIslāmī wa Adillatuhu, juz VI (Damaskus: Dār al-Fikr, 1409 H/1989), h. 215. 
pelaku pemukulan terhadap seorang wanita hamil dari Bani Lahyān, yang menyebabkan gugurnya janin dan matinya sang ibu. Dalam salah sebuah hadis yang diriwayatkan oleh Muslim, Abū Huriyrah menjelaskan: ${ }^{48}$

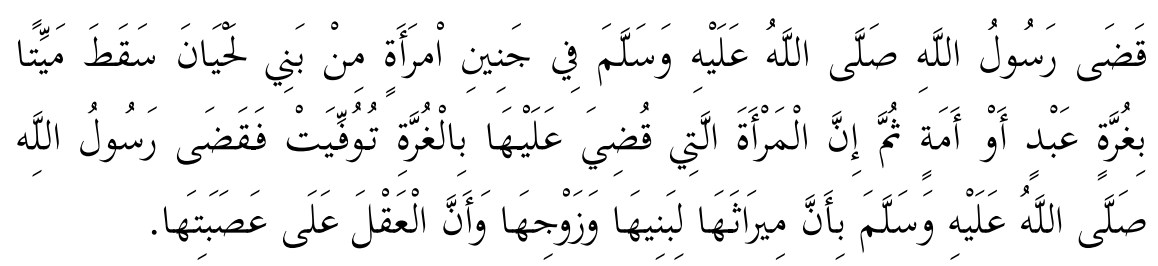

Rasulullah saw menetapkan atas janin seorang wanita Bani Lahyān yang gugur dalam keadaan mati, dengan al-ghurrah berupa seorang hamba laki-laki atau seorang hamba perempuan. Kemudian wanita yang ditetapkan baginnya al-ghurrah meninggal dunia, maka Rasulullah saw menetapkan ahli warisnya kepada anak-anaknya dan suaminya, sedangkan diyat kematiannya (sang ibu) diberikan kepada asłabahnya.

Berdasarkan hadis di atas, mayoritas ulama memandang pengguguran kandungan setelah ditiupkan ruh yang dilakukan dengan sengaja oleh si perempuan atau suaminya ataupun orang lain, diwajibkan membayar al-ghurrah ${ }^{49}$ berupa budak laki-laki atau budak perempuan. ${ }^{50}$ Kewajiban membayar al-ghurrah

${ }^{48}$ Hadis tersebut diriwayatkan oleh Abū Hurairah dalam berbagai versi. Lihat Abū al-Ḥusain Muslim bin al-Hajjāj al Qusyairī al-Naisābūrī, Ṣahīh ...., juz III, h. 1309.

${ }^{49}$ Kata al-ghurrah memiliki arti dasar al-bayāẹ fī wajh al-fars (belang putih di dahi kuda). Berdasarkan arti dasar tersebut, 'Amrū bin 'Alā menjadikan warna putih sebagai syarat bagi budak yang akan dijadikan bayaran. Akan tetapi mayoritas ulama tidak menjadikannya sebagai syarat, apalagi sulit mendapatkann budak yang berwarna putih. Kadar al-ghurrah sama dengan lima ekor unta. Manșūr Yūnus Idrīs al-Bahūtī, Kasyf al-Qinā' 'an Matn al-Iqnā', juz VI (Beirut: Dār al-Fikr, 1302 H/1982), h. 23; Syams al-Dīn Muhammad bin Muhammad al-Khatīb al-Syarbān̄i, Mughnī al-Muhtāj ilā Ma'rifat Ma'ānī Alfāz al-Manhāj, juz V (Beirut: Dār al-Fikr, 1415 H/1993), h. 369; al-Māwardī, al-Hāwī̄..., h. 212; dan Syams al-Dīn Muhammad bin Abī al-'Abbās Ahmad bin Hamzah bin Syihāb al-Dīn al-Ramlī, Nihāyat al-Muhtāj ilā Syarh alManhāj, juz VII (Mesir: Mușțafā al-Bābī al-Halabī wa Awlāduh, 1386 H/1967), h. 350-351.

${ }^{50}$ Al-ghurrah diartikan dengan budak laki-laki atau budak perempuan adalah pendapat mayoritas ulama. Sebagian ulama, seperti 'Urwah, Tāwūs dan 
merupakan denda atau diyah $h^{51}$ al-janīn yang paling sempurna bagi janin yang telah lengkap bentuk fisiknya.

Menurut al-Māwardī, para ulama berbeda pendapat tentang kriteria janin yang dibebankan membayar al-ghurrah bila digugurkan, baik dilakukan oleh sang ibu sendiri, dukun, dokter ataupun lainnya, tanpa ada alasan yang dibenarkan dalam agama. Perbedaan itu dapat dikalsifikasikan kedalam tiga golongan.

Golongan pertama, yakni al-Sya'bī, Imam Mālik dan alHasan bin S\{ālih, memandang bahwa kewajiban membayar alghurrah dibebankan kepada pelaku abortus sejak terjadi kehamilan. Untuk memperkuat pendapat mereka, Imam Mālik antara lain memberikan argumen yang menqiaskan hukuman bagi pembunuhan terhadap anak dan hukuman terhadap janin. Jika pembunuhan terhadap seorang anak diwajibkan membayar diyat, tanpa membedakan usia mereka (kecil atau besar), maka

Mujāhid, menambahkan al-fars (kuda) dan al-bagl (keledai) disamping budak laki-laki dan budak perempuan sesuai dengan artinya. Akan tetapi pendapat tersebut ditolak oleh Ibn Qudāmah dengan mengatakan bahwa hadis yang digunakan sebagai dasar hukum terdapat cacat. Kecacatannya terletak pada 'İsā bin Yūnus, dimana dia meriwayatkan sendiri hadis tersebut tanpa memperoleh dukungan dari siapapun. Oleh Ibn Qudāmah, hal tersebut dianggapnya sebagai wahm. Ibn Qudāmah, al-Mughnīwa..., juz IX, h. 540-541. Lihat juga al-Syarbān̄i, Mughnī..., h. 378; Taqī al-Dīn bin Taimiyyah, Majmū'āt Fatāwā Ibn Taimiyyah, juz IV (t.tp.: Dār al-Fikr, t.th.), h. 182.

${ }^{51}$ Al-Diyah dalam istilah agama adalah nama jenis pertanggungjawaban berupa harta yang dibebankan (kepada pelaku) akibat kejahatan yang dilakukan terhadap manusia atau anggota badannya. Kewajiban membayar aldiyah hanya dibebankan kepada pelaku pembunuh alpa (al-qatl al-khata') atau semi sengaja (al-qatl syibh al-'amd), sedangkan pembunuhan yang disengaja (al-qatl al-'amd), hukumannya menurut ijma' ulama adalah qișaș. Adapun diyat al-qatl terhadap muslim merdeka, maka ijma' ulama menetapkannya senilai 100 ekor unta. Bila diyat tersebut diukur dengan selain unta, dalam hal ini para ulama berbeda pendapat. Ibrāhīm bin Khālid bin Abī al-Yamān alBaghdādī, Fiqh al-Imām Abī Śaur (Beirut: Mu'assasat al-Risālah, 1403 H/1983), h. 683-684. 
sudah sepantasnya ketentuan al-ghurrah pun diterapkan bagi pelaku abortus, baik pada awal kehamilan maupun akhir. ${ }^{52}$

Golongan kedua, yakni Abū Hanīfah, berpendapat bahwa jika abortus dilakukan terhadap janin yang belum sempurna bentuknya, maka pelakunya tetap diberi hukuman. Akan tetapi, bila janin tersebut telah berbentuk manusia sempurna, maka pelakunya dibebankan membayar al-ghurrah. ${ }^{33}$ Abū Hanīfah menjadikan bentuk fisik janin tersebut sebagai pedoman dalam menentukan hukuman bagi pelakunya. Jika abortus dilakukan terhadap janin yang telah sempurna bentuk fisiknya dibebankan membayar al-ghurrah, maka abortus terhadap janin yang belum sempurna bentuknya, diberikan hukuman yang lebih ringan dari al-ghurrah.

Golongan ketiga adalah golongan yang membebaskan kewajiban membayar al-ghurrah bagi pelaku abortus, jika janin belum sempurna bentuknya. Kewajiban al-ghurrah hanya dibenbankan kepada pelakunya, manakala janin yang digugurkan telah sempurna bentuk fisiknya. Pendapat ini antara lain dikemukakan oleh al-Syāfi'î dengan mengemukakan dua pertimbangan sebagai alasannya. Pertama, bahwa adanya kewajiban membayar denda muncul karena adanya larangan (keharaman), sedangkan janin yang belum mencapai kesempurnaannya tidak terdapat larangan di dalamnya dan masih dianggap sebagai al-nutfah. Kedua, bahwa sesungguhnya kehidupan manusia berada di antara dua keadaan, yaitu antara keadaan pada tahap awal penciptaannya dan keadaan setelah kematiannya. Jika keadaannya setelah kematian tidak memperoleh konsekuensi hukum, maka demikian pula halnya dengan keadaan janin pada tahap awal kejadiannya. ${ }^{54}$

${ }^{52}$ Al-Māwardī, al-Hāwī̄..., h. 208-209. Bandingkan dengan al-Jazīin̄, Kitāb al-Fiqh..., h. 330.

${ }^{53}$ al-Jazīrī, Ibid., h. 326; al-Māwardī, ibid.

${ }^{54}$ Al-Māwardī, Ibid., h. 209. 
Para ulama juga memperbincangkan konsekuensi hukuman bagi pelaku abortus, dengan melihat keadaan janin setelah digugurkan. Dalam hal ini keadaan janin tersebut dapat diklasifikasikan kedalam dua kelompok, yaitu janin yang digugurkan dalam keadaan mati dan janin yang digugurkan dalam keadaan hidup.

Dengan tetap berpedoman kepada hadis di atas, apabila sang ibu dengan sengaja menggugurkan kandungannya misalnya dengan meminum obat atau memukul perutnya dan lahir dalam keadaan hidup - baik laki-laki maupun perempuan, maka dia dijatuhi kewajiban membayar diyat al-janin bagi pelakunya, yaitu al-ghurrah. ${ }^{55}$ Sebagian ulama menambahkan kewajiban membayar al-kaffārah, ${ }^{56}$ disampinng al-ghurrah. Kewajiban membayar al-kaffārah dimaksudkan sebagai hukuman agama (الجزاء الديني) sedangkan membayar al-ghurrah sebagai hukuman pidana (الجز اء الجنائي).

Berbeda halnya dengan janin yang digugurkan dalam keadaan hidup kemudian mati karena kejahatan yang dilakukan dengan sengaja. Menurut al-Mālikī, hukuman qisas lebih tepat diberikan kepada pelakunya bila kematian janin lebih dominan disebabkan oleh tindakan pelaku, seperti memukul perut atau punggung sang ibu. Apabila pukulan tersebut hanya ditujukan kepada tangan atau kaki sang ibu, maka pelakunya hanya

\footnotetext{
${ }^{55}$ Pendapat ini antara lain dikemukakan oleh Abū Ṡaur dan al-Syarbānī. Al-Baghdādī, Fiqh al-Imām..., h. 691-692; al-Syarbānī, Mughnī..., h. 368-369; Wahbat al-Rakhīlī, al-Fiqh al-Islāmī.., h. 362.

${ }^{56}$ Kewajiban membayar al-kaffärah adalah dengan memerdekakan budak. Bila tidak mampu, diganti dengan puasa dua bulan berturut-turut. Bila inipun tidak mampu dilakukan, maka diganti dengan memberi makan atau pakaian kepada 60 orang miskin. Kewajiban membayar al-kaffärah ini antara lain dikemukan oleh al-Māwardī, ulama mazhab al-Syāfi'î dan Hanābilah. Sedangkan ulama mazhab al-Hanafī dan al-Mālikī hanya menganggap alkaffärah sebagai sunnah saja. Lihat misalnya Wahbat al-Rakhīlī, ibid., h. 364365; al-Azhar al-Syarīf, Bayān..., h. 256-257 ; Ibn Taimiyyah, Majmū'āt..., h. 182

${ }^{57} \mathrm{Al}$-Māwardī, al-Hāwī..., h. 208; al-Azhar al-Syarīf, ibid.
} 
dibebankan membayar denda dan bukan al-ghurrah, karena penyebab dominan kematian janin bukan akibat pukulan. Sedangkan ulama mazhab al-Hanafī, sebagaimana pula dikatakan al-Syāfi'ī dan al-Hanbalī, mewajibkan membayar al-ghurrah, baik janin dalam keadaan hidup maupun mati. Lebih dari itu, jika pukulan tersebut mengakibatkan kematian janin dan ibunya, maka bagi pelakunya dibebankan membayar diyat al-nafs atas kematian sang ibu dan al-ghurrah atas kematian janin. ${ }^{58}$

Hukuman terhadap pelaku abortus akan semakin meningkat dan berlipat ganda sesuai dengan jumlah janin yang digugurkan. Apabila janin yang digugurkan dengan sengaja berjumlah dua buah, maka bagi pelakunya diwajibkan membayar dua al-ghurrah dan demikianlah seterusnya. Bagi para ulama yang mewajibkan membayar al-kaffārah, maka kewajiban itupun akan berlipat ganda sesuai dengan jumlah janin yang digugurkan. ${ }^{59}$

Pernyataan lebih tegas dikemukan oleh ulama Mazhab alZāhirī dengan mengatakan bahwa pelaku abortus diancam hukuman qisas atau dengan diyat al-nafs ${ }^{60}$ jika dimaafkan, apabila janin yang digugurkan telah diberi nyawa dan berbentuk manusia sempurna. ${ }^{61}$ Tampaknya ulama Mazhab al-Zāhirī menyamakan status janin yang telah diberi nyawa dan lengkap bentuk fisiknya dengan manusia sempurna, sehingga hukuman bagi pelakunya disamakan dengan hukuman kejahatan pembunuhan dengan sengaja (القتل العمد).

Memperhatikan perbendaan pandangan di atas, secara umum para ulama melontarkan pendapat mereka masing-masing dengan berpedoman kepada hadis di atas atau yang semakna disamping nas Alquran. Akan tetapi, jika redaksi matan hadis

${ }^{58}$ al-Azhar al-Syarīf, ibid., h. 366; al-Jazīrī, Kitāb al-Fiqh..., h. 327.

${ }^{59}$ Lihat misalnya Al-Māwardī, al-Hāwī..., h. 208-209

${ }^{60}$ Ijma ulama menetapkan diyat pembunuhan yang disengaja dengan 100 ekor unta dan berbeda pendapat jika diukur dengan selain unta. Al-Baghdādī, Fiqh al-Imām..., h. 684.

${ }^{61}$ Ahmad Azhar Basyir, Refleksi..., h. 24. 
tersebut dianalisis lebih jauh, secara implisit dapat dipahami bahwa ancaman hukuman al-ghurrah berlaku secara umum. Ketentuan itu tidak dibatasi pada tahap tertentu dari proses kejadian manusia atau jenis kelamin janin. Itu berarti ancaman hukuman al-ghurrah dapat diterapkan bagi pelaku abortus secara mutlak pada setiap tahap kejadian manusia, baik laki-laki maupun perempuan.

Jika dipandang dari sisi korbannya, menurut hemat penulis, hukuman bagi pelaku abortus tidak dapat disamakan dengan hukuman bagi pelaku pembunuhan manusia dengan sengaja, yaitu qisas. Hal itu karena janin yang digugurkan kamungkinannya untuk hidup di alam nyata masih bersifat relatif, sementara keberadaan manusia di alam nyata sudah pasti. $^{62}$ Oleh karena itu, qisas hanya dapat diterapkan kepada pelaku pembunuhan sengaja terhadap manusia atau janin yang telah lahir dengan selamat.

Para ulama sepakat menetapkan kadar al-ghurrah dengan seorang hamba sahaya laki-laki atau hamba sahaya perempuan, sebagaimana telah dijelaskan di atas. Akan tetapi, jika al-ghurrah diaplikasikan dalam kehidupan kontemporer, agaknya istilah tersebut lebih tepat diartikan dengan pembayaran sejumlah uang sebagai denda, berdasarkan vonis pengadilan. Hal itu didasarkan atas fleksibilitas ajaran Islam yang berkembang sejalan dengan perkembangan pemikiran dan peradaban manusia. Disamping itu, praktek perbudakan sendiri sudah tidak ditemukan dalam kehidupan sekarang dan tidak dibenarkan lagi keberadaannya dalam Islam.

${ }^{62}$ Pada sisi lain, janin itu sendiri dipermasalahkan hukum keberadaannya oleh sebagian ulama. Sebagian ulama menganggap janin sebagai bagian dari anggota tubuh sang ibu, sementara sebagian lainnya memandang dari sudut pertumbuhan janin pada masa yang akan datang sehingga mereka mengkategorikannya sebagai jiwa yang terpisah dari ibunya. Lihat Wahbat alRakhīlī, al-Fiqh al-Islāmī.., h. 216. 
Para ulama berbeda pendapat tentang siapa yang menanggung denda kejahatan pengguguran. Ulama al-Syāfi'î dan ulama al-Hanafī yang memandang abortus sebagai kejahatan pembunuhan alpa (القتل الخطأ) atau kejahatan semi sengaja (القتل شبه (العمد), berpendapat bahwa denda tersebut dibebankan kepada keluarga pelaku (عاقلة الجاني) bukan kepada pelaku (الجاني).63

Ulama Mazhab al-Hanbalī melihat hal tesebut dari dua sudut pandang. Pertama, jika abortus tersebut menewaskan janin dan ibunnya, maka kejahatan itu dianggap sebagai kejahatan yang disengaja atau kejahatan semi sengaja. Karenanya, keluarga pelaku dibebankan membayar diyat atas jiwa si ibu dan alghurrah atas si janin. Kedua, jika kejahatan tersebut dilakukan dengan sengaja terhadap si ibu, atau janinnya saja yang meninggal, maka dalam hal ini keluarga pelaku tidak dibebankan apapun karena tanggungan itu hanya dibebankan kepada pelakunya sendiri. Sementara itu, ulama al-Mālikī berpendapat bahwa al-ghurrah itu diwajibkan kepada pelaku karena kesamaannya dengan diyat pada kejahatan yang disengaja, sungguhpun mereka sepakat dengan jumhur ulama bahawa kejahatan terhadap janin bukanlah kejahatan disengaja. Namun demikian, ada kemungkinan sengaja terhadap ibunya, tetapi alpa terhadap janin.

Terlepas dari pandangan para ulama di atas, penulis berpendapat bahwa kewajiban membayar diyat aljanīndibebankan kepada pelaku yang terlibat, baik dokter, suster, dukun ataupun ibu janin itu sendiri, apabila abortus dilakukan dengan sengaja dan ditujukan kepada janin. Pandangan ini didasarkan atas keterlibatan mereka, baik langsung maupun tidak langsung, dalam merealisasikan kejahatan tersebut. Allah sendiri

${ }^{63}$ Al-Jazīrī, Kitāb al-Fiqh..., h. 326. Pendapat serupa dikemukakan oleh alMāwardī bahwa kewajiban membayar al-ghurrah dibebankan kepada keluarga pelaku karena mereka dianggap terlibat secara tidak langsung dalam merealisasikan kejahatan tersebut. Kepada pelakunya dibebankan membayar al-kaffārah. Lihat al-Māwardī, al-Hāwī..., h. 208-209 
telah menandaskan larangan untuk saling tolong menolong dalam kejahatan. $^{64}$

Disamping itu, bila al-ghurrah dianalogikan dengan aldiyah, tampaknya ada kesamaan dari segi kewajibannya kepada pelaku atau keluarga pelaku. Al-Diyah atau denda kejahatan pembunuhan disengaja diwajibkan kepada pelakunya sendiri, sementara kejahatan yang tidak disengaja dikenakan kepada keluarga pelaku. ${ }^{65}$ Ketentuan ini dapat diaplikasikan kepada alghurrah sebagai kejahatan pengguguran. Jika unsur kesengajaan lebih dominan daripada unsur ketidaksengajaan dalam suatu kejahatan pengguguran, misalanya pengguguran yang dilakukan untuk menutup malu akibat perzinahan, maka tidak berlebihan jika kewajiban al-ghurrah pun dibebankan kepada seluruh pelaku yang terlibat didalamnya dan bukan keluarga pelaku, kecuali jika diantara mereka ada yang terlibat. Kewajiban menyelesaikan tanggungan diyat al-janīn baru dapat dibebankan kepada keluarga pelaku abortus, jika pengguguran itu dilakukan dengan tidak sengaja.

Sejalan dengan matan hadis di atas, melakukan kejahatan terhadap wanita hamil yang mengakibatkan gugurnya kandungan, maka jumhur ulama lebih dekat dengan pendapat yang menyamakan ahli waris al-ghurrah dengan ahli waris diyat al-qātil. ${ }^{66} \quad$ Artinya, al-ghurrah menjadi hak janin yang harus dibagikan kepada ahli warisnya. Akan tetapi, jika perempuan itu sendiri yang melakukan abortus, maka dia wajib membayar alghurrah dan tidak berhak mmenerima apa-apa meskipun dia termasuk ahli waris janin. ${ }^{67}$

${ }^{64} \mathrm{QS}$. al-Mā'idah (5): 2.

${ }^{65}$ Wahbat al-Rakhīlì, al-Fiqh al-Islämī..., h. 363.

${ }^{66}$ Ibn Rusyd, Bidāyat al-Mujtahid, juz II (Indonesia: Dār Ihhyā' al-Kutub al-'Arabiyyah, t.th.), h. 312; dan Ibn Qudāmah, al-Mughnīwa..., juz VII, h. 805.

${ }^{67} \mathrm{Al}-J a z \bar{r} \mathbf{r} \overline{1}$, al-Jazīīi, Kitāb al-Fiqh..., h. 331; al-Bahūtī, Kasyf al-Qinā' 'an ..., h. 24; Ibn Hazm, al-Muhalā..., h. 384; Wahbat al-Rakhīlī, al-Fiqh al-Islāmī..., h. 364 . 
Demikanlah Islam sangat menghormati eksistensi manusia sejak awal penciptaannya. Penganiayaan terhadp janin dengan menghentikan pertumbuhannnya menjadi manusia sempurna tanpa alasan hukum tidak dibenarkan dalam agama. Perbuatan tersebut dikategorikan sebagai suatu kejahatan, sementara pelakunya diancam dengan hukuman yang sangat berat.

\section{DAFTAR PUSTAKA}

\section{Al-Qur'ān al-Karìm.}

Abū Zahrah, Muhammad. Ușūl al-Fiqh. T.tp.: Dar al-Fikr al-'Arabī, t.th.

Anīs, Ibrāhim, dkk. Al-Mu'jam al-Wasịt. T.tp.: t.p., t.th.

Al-Azhar al-Syarīf. Bayān li al-Nās. T.tp.: al-Matba'at al-Azhar, t.th.

Basyir, Ahmad Azhar. Refleksi Atas Persoalan Keislaman; Seputar FilsafatHukum, Politik dan Ekonomi. Bandung: Mizan, 1994.

Al-Bukhārī, Abū 'Abdullāh Muhammad bin Ismā'îl. S\{ahīh alBukhārī. Indonesia: Maktabat Dahlan, t.th.

Al-Burnū, Muhammad Sidqībin Ahmad. Al-Wajīz fī İdhāh Qawā'id al-Fiqh al-Kulliyah. Beirut: Mu'assasat al-Risālah, 1404 $\mathrm{H} / 1983$.

Departemen Agama Republik Indonesia. Al-Quran dan Terjemahnya. Jakarta: Proyek Penggandaan Kitab Suci AlQuran Departemen Agama RI., 1994.

Echols, Jhon M. dan Hasan Sadily. Kamus Inggris-Indonesia. Jakarta: PT. Gramedia, 1990.

Al-Ghazālī. Ihyā' 'Ulūm al-Dīn. T.tp.: Dār Ihyā' al-Kutub al'Arabiyyah, t.th.

Haq, Hamka. “Aspek-aspek Teologis dalam Konsep Maslahat menurut al-Syatibīsebagai terdapat dalam al-Muwafaqat," Disertasi. Jakarta: IAIN Syarif Hidayatullah, 1989. 
Heller, Martin. International Family Heart Encylopedia. London: Orbis Publising Ltd., 1971.

Ibn 'Ābidīn, Muhammad Amīn. Hāsyiyah Ibn 'Ābidīn. Mesir: Mus\}tafā al-Bābī al-Halabī, 1386 H/1966.

Ibn Hazm, Abū Muhammad 'Alībin Ahmad bin Sa'îd. Al-Muhallā. Mesir: Maktabat al-Jumhuriyyat al-'Arabiyyah, 1391 H/1971.

Ibn Manzhūr, Muhammad bin Mukarram. Lisān al-Arab. Mesir: Dār al-Mis\}riyyah, t.th.

Ibn Qudāmah, Muwaffiq al-Dīn AbīMuhammad 'Abdillāh bin Ahmad. Al-Mughnīwa al-Syarh al-Kabīr 'alā Matn alMughnī. Beirut:Dār al-Fikr, 1412 H/1992.

Ibn Taimiyah, Taqīal-Dīn. Majmū'àt Fatāwā Ibn Taymiyah. T.tp.: Dār al-Fikr, t.th.

Ibn Zakariyā, Abū al-Husayn Ahmad bin Fāris. Mu'jam Maqāyīs alLugah. T.tp.: Dār al-Fikr, 1394 H./1979.

Al-Jazīrī, 'Abd al-Rahmān. Kitāb al-Fiqh 'alā al-Mazāhib alArba'ah. Beirut: Dār al-Kutub al-'Ilmiyyah, 1410 H/1990.

Khallāf, 'Abd al-Wahhāb. 'Ilm Us\}ūl al-Fiqh. T.tp.: Maktabat alDa'wat al-Islāmiyyah, t.th.

Lane, Edwardd William. An Arabic-Englis Lexicon. Lebanon: Librarie Du Liban, 1968.

Al-Māwardī, Abū al-Hasan 'Alībin Muhammad bin Habīb. AlHāwīal-Kabīr. Beirut: Dār al-Fikr, 1414 H/ 1994.

Mochtar, Rustam. Sinopsis Obstetri: Obstetri Fisiologi, Obstetri Patalogi. Jakarta: Penerbit Buku Kedokteran EGC, 1990.

Mukti, Ali Ghufran dan Adi Heru Sutomo. Abortus, Bayi Tabung, Eutanasia, Transplantasi Ginjal dan Operasi Kelamin dalam Tinjauan Medis, Hukum dan Agama Islam. Yogyakarta: Aditya Media, 1993. 
Al-Naisābūrī, Abū al-Husayn Muslim bin al-Hajjāj al-Qusyairī. ȘahīhMuslim. Indonesia: Maktabah Dahlan, t.th.

Nugroho, E. dkk. Ensiklopedi Nasionnal Indonesia. Jakarta: PT. Cipta Adi Pustaka, 1990.

Al-Qardhāwī, Yūsuf. Al-Halāl wa al-Harām fī al-Islām. Beirut: Maktab al-Islāmī, 1978.

Qutb, Sayyid. FīZhilāl al-Qur'ān, juz IV. Kairo: Dār al-Masyrūq, $1412 \mathrm{H} / 1992$.

Al-Rakhīlī, Wahbah. Al-Fiqh al-Islāmīwa Adillatuh. Damaskus: Dār al-Fikr, 1409 H/1989.

Ramli, Med. Ahmad dan K. St. Pamoentjak. Kamus Kedokteran. Jakarta: Djambatan, 1992.

Al-Ramlī, Syams al-Dīn Muhammad bin Abīal-'Abbās Ahmad bin Hamzah bin Syihāb al-Dīn. Nihāyat al-Muhtāj ilā Syarh alManhāj. Mesir: Mușțafā al-Bābīal-Halabī wa Awlāduh, 1386 H/1967.

Rusyd, Ibn. Bidāyat al-Mujtahid. Indonesia: Dār Ihyā’ al-Kutub al'Arabiyyah, t.th.

Sadily, Hassan, dkk. Ensiklopedi Indonesia. Jakarta: Ichtiar Baru Van Hoeve, 1980.

Sills, David L. (ed.), International Encyclopedia of the Social Sciences. New York: The Macmillan Company and The Free, 1972.

Syaltūt, Mahmūd. Al-Islām 'Aqīdah wa Syari'ah. Kairo: Dār alQalam, 1966.

al-Syarbānī, Syams al-Dīn Muhammad bin Muhammad al-Khatīb. Mughnīal-Muhtāj ilā Ma'rifat Ma'ānī Alfāz al-Manhāj. Beirut: Dār al-Fikr, 1415 H/1993.

Al-Syātibī, Abū Ishāq.Al-Muwāfaqāt fĩus\}ūl al-Syarīah. Mesir: alMaktabat al-Tijāriyyat al-Kubrā', t.th. 
Al-Syirbāsī, Ahmad. Yas'alūnaka fī al-Dīn wa al-Hayāh. Beirut: Dār al-Jayl, 1980.

The Encyclopedia Americana, jilid XIV. U.S.A.: Americana Corporation, h.548.

Tim Penyusun Kamus Pusat Pembinaan dan Pengembangan Bahasa. KamusBesar Bahasa Indonesia. Jakarta: Balai Pustaka, 1990.

Al-Tirmizī, Abū Isā Muhammad bin 'Īsā bin Saurat. Sunan alTirmizì. Indonesia: Maktabat Dahlan, t.th.

Zuhdi, Masjfuk. Masail Fiqhiyah. Jakarta: Haji Masagung, 1993. 